\title{
Urban form and social cohesion: the socio-morphological definition of the residential fabrics of the Metropolitan Area of Barcelona
}

\author{
Rosina Vinyes ${ }^{1}$, Sergio Porcel $^{2}$, Fernando Antón-Alonso ${ }^{2}$, Mariona \\ Figueras $^{1}$, Laia Molist ${ }^{1}$ \\ ${ }^{1}$ Servei de redacció del pla director urbanístic. Serveis d'Urbanisme. \\ Àrea Metropolitana de Barcelona. Barcelona, Spain \\ ${ }^{2}$ Àrea de cohesió social i urbana. Institut d'estudis regionals i metropolitans de Barcelona. \\ Barcelona, Spain \\ E-mail: sergio.porcel@uab.cat, fernando.anton.alonso@uab.cat
}

\begin{abstract}
Social inequality has become of great importance nowadays, and it is in metropolitan areas where it appears to be more intense. Thus, inequality becomes unavoidable when rethinking the contemporary cities. To get a grasp of this phenomenon, for the first time in the metropolitan area of Barcelona, a common look between urban morphology and social cohesion is made. The goal is to describe the socio-morphologic structure of the metropolitan territory, which is the result of combining both categorizations and maps of the existing sociological and morphological aspects. For such purpose, a twostage methodology has been used. The first stage develops the quantitative and qualitative criteria to overlap the two existing maps, and stablishes the areas that will be considered the new socio-morphologic fabrics. The second one applies the areal interpolation method to assign this socioeconomic and/or demographic information to these new fabrics. The result of this combination is a categorization of twenty-one types of fabrics that describes the sociomorphological metropolitan reality. This new categorization sheds light on a tight relationship between urban shape and social cohesion, both conditioning each other. Moreover, the new map shows socio-morphological similarities between distant areas and announces common urban strategies to achieve a larger urban equity. The interest of having this new approach increases when thinking in the new investigation lines that will be derived from there. One of them would be the evolutionary reconstruction, which will allow visualizing processes and ease the understanding of certain phenomena to foresee urban blight.
\end{abstract}

Keywords: Barcelona, Urban fabric, Socio-residential areas,

Socio-morphological structure.

\section{Introduction}

Social inequality has taken on a great deal of importance in western societies, especially after the onset of the major economic and financial crisis in 2008. It is a problem of great urban importance, since it is a phenomenon that is most intensely apparent in large cities. According to Secchi (2015), social inequality now comprises the new urban issue, and so he places it as a factor that must necessarily be taken into account for the process of (re)construction of today's metropolises. Unfortunately, the Barcelona metropolitan area has not been immune from this problem, which has been exacerbated by the effects that have arisen with the most recent economic recession. The steep rise in unemployment and limitations 
of the social welfare system have contributed to a significant escalation of poverty and social inequality in this conurbation in recent years, reversing a lengthy process of social cohesion that had begun with the reinstatement of democracy (Sarasa et al., 2013).

However, urban inequality goes beyond social inequality and its territorial shaping. Urban inequality implies consideration of the territorial effect in the reproduction or the worsening of social inequality (Harvey, 1977). In that connection, in addition to differences in income levels among the population, we need to take into account factors such as housing maintenance costs, living conditions, the quality of the residential environment, connections serving residential areas or the degree of conflict affecting public spaces, among others. From that standpoint, the urban territory constitutes a substantial portion of the structure of opportunities available to its residents, in part determining their living conditions. Intervention in this socio-territorial dimension is crucial to attaining improved urban cohesion.

Given those urban "disorders" characteristic of capitalist cities, in the 1970s Lefebvre (1969) coined the notion of the right to the city, in defence of the ability to conceive and (re) construct a different sort of city, focussed on people and distanced from the chaos generated by the insatiable pursuit of profit maximisation. In that connection, urban planning and urban policies are key instruments to correct and monitor those pernicious processes in the production of urban space and to make cities fairer and more inclusive places to live. The concept of urban cohesion, in contrast with urban inequality, furnishes a theoretical and practical construct that fits with those objectives. Adopting the notion of urban cohesion from politics and social science's standpoint involves a paradigm shift that, while not diametrically opposed to the more conventional approaches to analysis and act against urban inequality, it does represent an expansion and improvement on those approaches.

In that regard, during the course of 2016 and within the framework of the preparatory work on the Barcelona Metropolitan Urban Master Plan, the Barcelona Institute of
Regional Metropolitan Studies (IERMB), working jointly with Master Plan Drafting Service of the Barcelona Metropolitan Area Urban Planning Services Department (SRPD), drew up a background document to provide guidelines for urban planning and urban policies. This was an interdisciplinary effort, accomplished jointly by architects, geographers and sociologists that, among other factors, contributes information on the sociomorphological structure of the Barcelona Metropolitan Area that had not previously been available, showing the relationship between the social status and the urban form of residential fabrics on a socio-morphological map. The preparation of that information was the result of the implementation of a cartographic synthesis of the morphological dimension and the social dimension of the Barcelona metropolis. That methodological innovation will help to continue expanding knowledge as to how physical and social factors interact in the urban context, thereby facilitating the decision-making process on matters of urban planning.

\section{Methodology}

The methodology used to outline the sociomorphological structure of the metropolitan area involves three separate phases, elaborated upon below: categorisation and map of the socio-residential areas of the Barcelona

Table 1.

Sociological variables used

\begin{tabular}{|c|c|}
\hline \multicolumn{2}{|l|}{ Sociological variables } \\
\hline \multicolumn{2}{|l|}{ Location } \\
\hline \multicolumn{2}{|l|}{ Size and population } \\
\hline Factors linked to social status & $\begin{array}{l}\text {-Income level } \\
\text {-Education } \\
\text {-Unemployment rate }\end{array}$ \\
\hline Life course & -Type of dwelling \\
\hline \multicolumn{2}{|l|}{ Geographic origin of population } \\
\hline $\begin{array}{l}\text { Factors linked to ease of access } \\
\text { to housing and living conditions }\end{array}$ & $\begin{array}{l}\text {-System of holding } \\
\text {-Dwelling size } \\
\text {-Building condition } \\
\text {-Availability of heating }\end{array}$ \\
\hline $\begin{array}{l}\text { Ease of access to facilities and } \\
\text { green zones and recreational } \\
\text { areas }\end{array}$ & $\begin{array}{l}\text {-Non-compulsory education } \\
\text {-Compulsory education } \\
\text {-Provisions } \\
\text {-Health care } \\
\text {-Social services }\end{array}$ \\
\hline
\end{tabular}




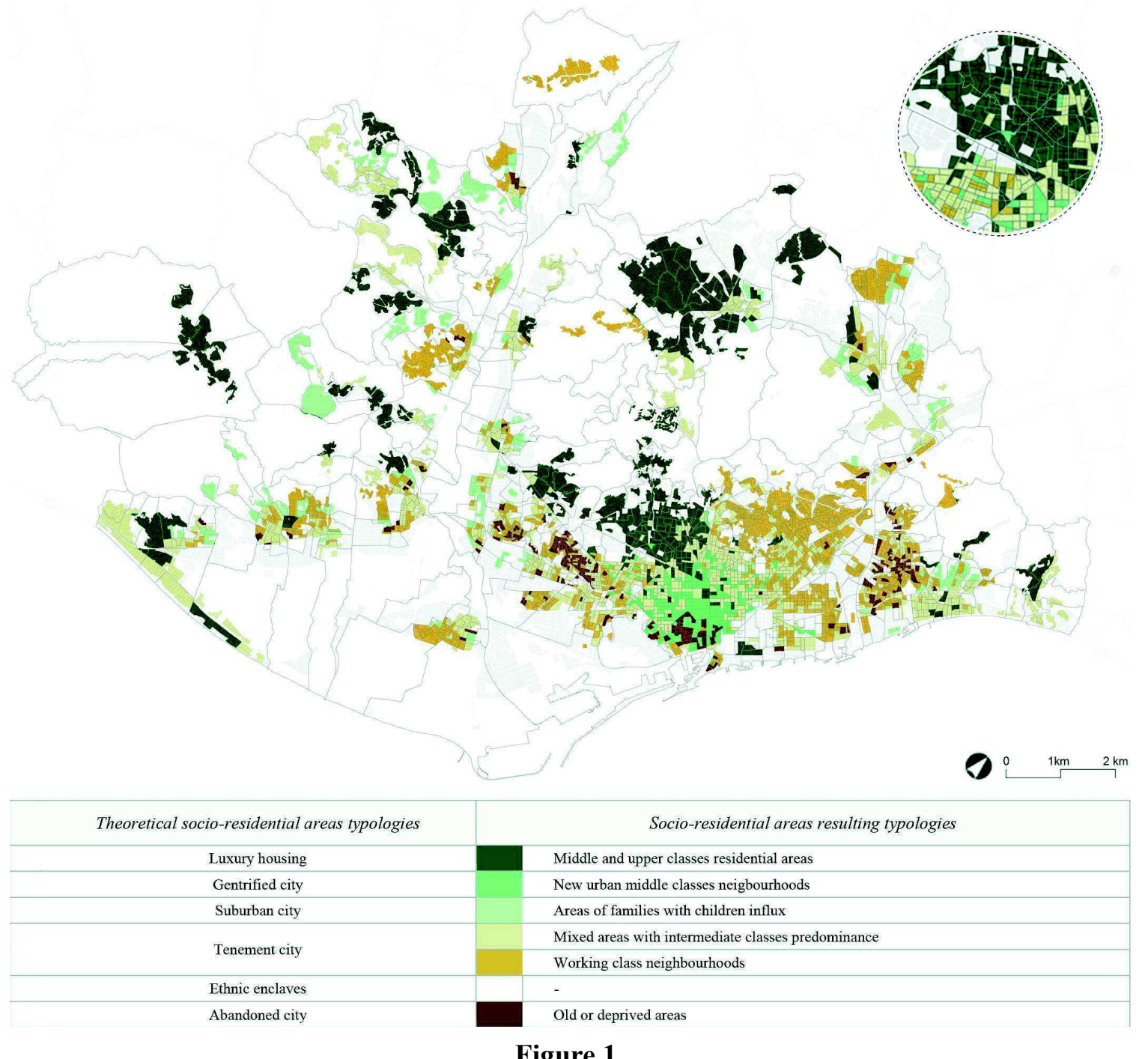

Figure 1.

Map of the socio-residential structure of the Barcelona metropolitan area (IERMB, 2011)

metropolis in 2011, made by IERMB; determination of morphological categories and the corresponding map of residential fabrics of the Barcelona metropolis in 2016, made by SPRD; and combination of the two studies to arrive at the new socio-morphological categories that, along with the map, explain the socio-morphological structure of the Barcelona conurbation in 2017.

1) Categorisation and map of socio-residential areas of the Barcelona metropolis in 2011 (IERMB)

The starting point for analysis of socioresidential differentiation in the Barcelona metropolis consists of knowing its structure and how it has arrived at that structure. The theoretical basis adopted were the socioresidencial typologies developed by Peter Marcuse and Ronald Van Kempen, which is highly sensitive in matters of the relationships between social structure and urban territorial morphology (Marcuse, 1993; Marcuse and Van Kempen, 2000, 2002). Based upon these typologies, analysis of census figures and cartographic data and a survey on living conditions and habits of the population (Table 1), the socio-residential categories in respect of the scope of the study and the corresponding map were established (Figure 1).

The method followed comprises two phases. The first involves construction of a typology of socio-residential areas that serves to structure 
the territory being studied based upon a sequence of analysis of main components and automated analysis of classification. In the second phase, the different types of socio-residential areas are described and analysed based upon the combination of social information provided by the survey and territorial information based upon GIS layers.

A brief description of the different types of residential areas follows:

-The Middle and upper classes residential areas are those comprising the higher social levels and where larger and higher quality dwellings predominate. Over two thirds of the population are managers or professionals and almost half receive high incomes.

-The New urban middle classes neigbourhoods have emerged in recent years and they correspond above all to processes of transformation of the metropolitan social structure in the post-industrial and globalised context. Here the predominant profile is that of qualified professional, with a substantial component of foreigners living alone or in couples without children, in rental accommodation.

-Those Areas of families with children influx emerged around the turn of the century. The main trait is predominance of home-owner families who have moved there recently and with mortgage debt. They are of a temporary nature and they are directly associated with the patterns resulting from the real estate boom between 1997 and 2007, influenced by easy credit conditions.

-Those Mixed areas with intermediate classes predominance are highly heterogeneous and they are home mainly to semi-qualified employees in services, although there is also a noticeable presence of qualified workers, mainly white-collar, Catalan-speaking office workers.

-Those Working class neighbourhoods arose as suburbs of Barcelona to house many of the immigrant workers from the rest of Spain. They house the majority of the unqualified population, particularly industrial, bluecollar workers, although with the evolution of deindustrialisation, they have been gradually replaced by unqualified employees in services.

-Those Old or deprived areas comprise old city centres, neighbourhoods with substantial urban planning deficits and run-down urban areas that house the population with the fewest resources, in both financial and social terms. One-person households predominate here, with ageing population or unqualified and more precarious unqualified workers, both nationals and foreigners born mostly in poor countries.

2) Categorisation and map of residential fabrics of the Barcelona metropolis in 2016 (SPRD)

In spite of the large size of the Barcelona metropolitan area, $636 \mathrm{~km}^{2}$, a substantial portion of the residential territory comprises repetitive patterns and forms that may be treated as fabrics. The subject of this work is the identification and conceptual and graphic definition, from a morphological standpoint, of the contemporary residential fabrics of Barcelona metropolis.

The morphological classification was made taking into account 5 compositional principles, along with the use of graphic and alphanumerical figures (Table 2). The

Table 2.

Morphological variables used

\begin{tabular}{|c|c|}
\hline \multicolumn{2}{|l|}{ Morphological variables } \\
\hline General data & $\begin{array}{l}\text {-Land } \\
\text {-Built up area } \\
\text {-Population } \\
\text {-Number of zones and average } \\
\text { size of zones }\end{array}$ \\
\hline $\begin{array}{l}\text { Physical factors of the urban } \\
\text { context }\end{array}$ & $\begin{array}{l}\text {-Road width } \\
\text {-Ratio of built-up area to road } \\
\text {-Occupied and open spaces } \\
\text {-Heritage } \\
\text {-Average block size } \\
\text {-Topography } \\
\text {-Vegetation }\end{array}$ \\
\hline $\begin{array}{l}\text { Functional factors of the urban } \\
\text { context }\end{array}$ & $\begin{array}{l}\text {-Ease of access } \\
\text {-Connectedness } \\
\text {-Private areas } \\
\text {-Public areas } \\
\text {-Facilities } \\
\text {-Green zones and roads }\end{array}$ \\
\hline $\begin{array}{l}\text { Physical factors of height } \\
\text { of the plot and building }\end{array}$ & $\begin{array}{l}\text {-Height } \\
\text {-Year built } \\
\text {-Compactness } \\
\text {-Buildings permitted } \\
\text {-Length of façade } \\
\text {-Land occupation } \\
\text {-Average built-up area } \\
\text {-Size of plot }\end{array}$ \\
\hline $\begin{array}{l}\text { Functional factors of plot and } \\
\text { building }\end{array}$ & $\begin{array}{l}\text {-Population density } \\
\text {-Dwelling density } \\
\text {-Dwelling size } \\
\text {-Residential use and other uses }\end{array}$ \\
\hline
\end{tabular}




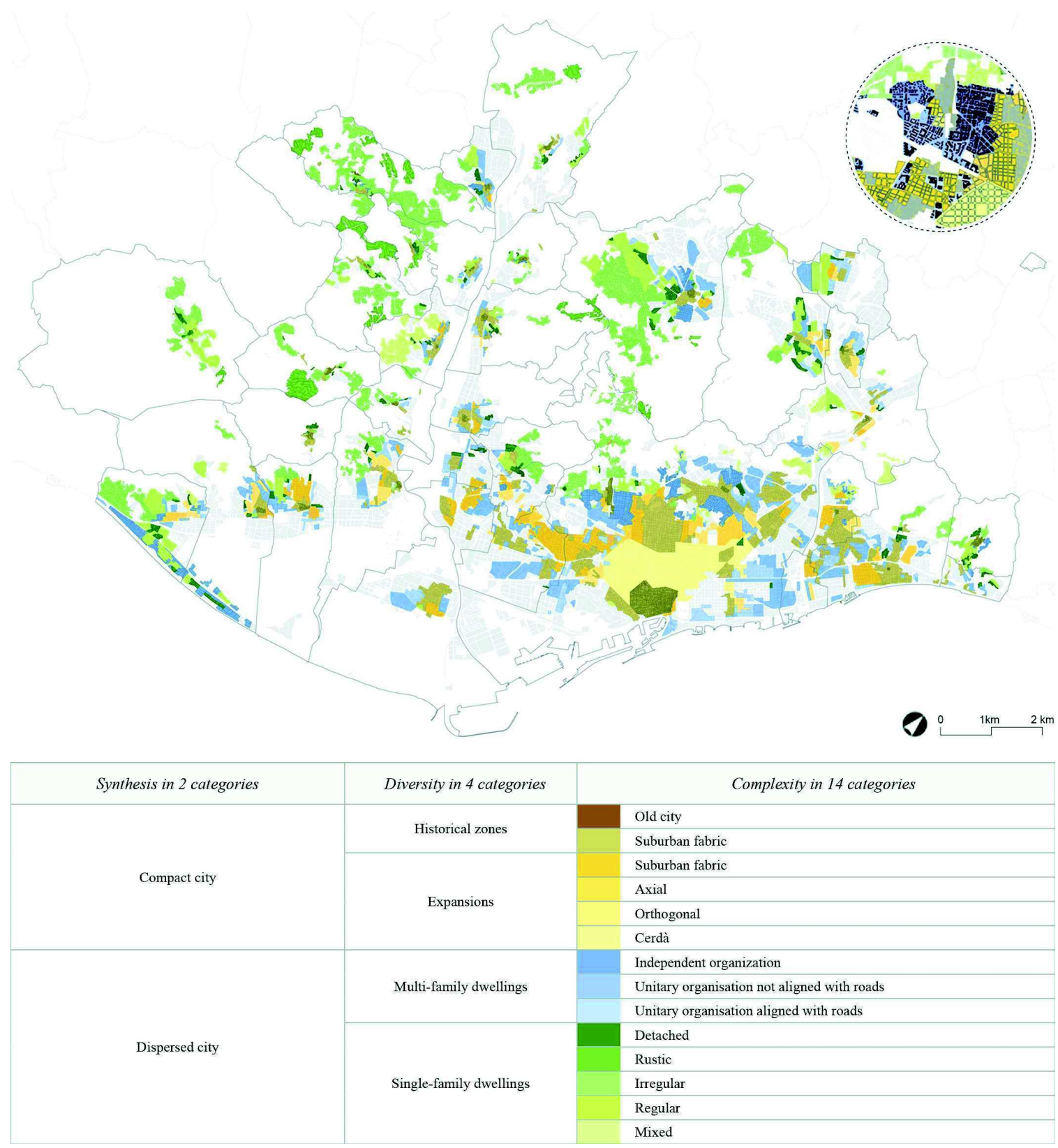

Figure 2.

of residential morphological fabrics in the Barcelona metropolitan area (SRPD-AMB, 2016)

first principle is transferability, inclusion of knowledge from preceding works, relating to morphology (Busquets, 2015; SolàMorales, 1993; Vilanova, 1997). The second is significance, each category must have qualitative and quantitative importance. The third is hierarchical structure, ordering the set of categories in ranked division. The fourth is unique nature, the categories must be mutually exclusive. Finally, completeness, the classification must include all the residential fabrics of the metropolitan area.
In conceptual terms, there are three levels of categories, in three large groups thatcomplement each other, to allow precise description of the variables of the metropolitan residential morphological reality (Table 2). Within the categories of Compact City and Dispersed City, there is a great deal of morphological diversity, and a number of groups are established to supplement and qualify them: metropolitan plurality and complexity in four and fourteen categories, respectively. The essential factors are the following: 
-Primitive fabrics: Balance between occupancy and space; a peculiar urban fabric; proximity, friction and variety; strong personality; diversity of uses and activities. The subcategories of Old City and Suburban fabrics are differentiated mainly in terms of regular or irregular layout, identity and facilities, densities and age.

-Expansions: Balance between occupancy and space; geometric layout; repetition and homogeneity; highest density and compactness; and greatest diversity of uses. The four types of Expansions are differentiated mainly by geometrics, density, street widths, topography and accessibility.

-Multi-family dwellings: dominance of open spaces; plots are larger; building typology of multi-family dwellings; high proportion of green areas and public facilities, but lack of identity points. The different subcategories are differentiated mainly in terms of density and land use, organisation of volumes, systems land use and quality of open spaces.

-Single-family dwellings: open spaces dominate; dwellings are single-family; lowest density; low degree of consolidation; predominantly monofunctional character. Subcategories are differentiated by topography and accessibility, roadways, density and land use.

In respect of the graphic demarcation and the corresponding map (Figure 2), the scope of the study extends to the actual built-up area and the degree of precision is given by the small scale, at plot level, to arrive at the consistent areas resulting from the grouping of city blocks.

3) Categorisation and map of sociomorphological fabrics of the Barcelona metropolis in 2017 (SRPD + IERMB)

The availability of the sociological and morphological maps presented allows us to draw a map of the overall territory being studied that juxtaposes those two factors. That combination must address two complexities: the criteria for superimposition and data reassignment.

The objective of the first phase is to determine the criteria for making the combination of the basic demarcations while maintaining the sociological and morphological essence. While the map of socio-residential areas has the demarcation of census tracts as its basic unit, the map of morphological fabrics has the layout of lots of the topographic base. Therefore, the following three decisions are taken into account:

1.Demarcation of socio-morphological fabrics: The reference unit taken is the demarcation of the 14 morphological fabrics, on the grounds that they are more representative of the territorial reality than the demarcation of census tracts, which are strictly administrative. However the names of the 4 morphological categories are kept instead of the 14 , to avoid excessive complexity of the resulting categories. This allows us to arrive at smaller fabrics and therefore a more consistent relationship with smaller-sized census tracts. In those cases where the divisions based upon morphological criteria still give very large fabrics in relation to the census tract, they are subdivided, using, first of all, the division into neighbourhoods based upon their boundary condition consolidated and validated over time, and subsequently, in the few cases where it has been necessary, the boundaries of the census groups or census tracts have been used.

2.Definition of social status: Based upon those divisions, it was agreed that socioresidential area taken as dominant should be the one with over $60 \%$ of a socio-morphological fabric. Of the 975 polygons, there are 91 cases where that percentage is lower and it is determined that at most they may be defined using two social variables. The two with the highest percentages are taken, since in any event the sum of the two is always higher than $60 \%$.

3.Definition of the representative categories and assimilation of the non-representative categories: There are categories that represent such a small proportion that they cannot be considered as such. The cut-off point is established at those with either fewer than 6 units or that represent less than $6 \%$ of their morphological category. There are 25 categories found to be so, and they are assimilated in accordance with the following four criteria. First of all, "Primitive" is assimilated into "Expansions", and taking into account their 


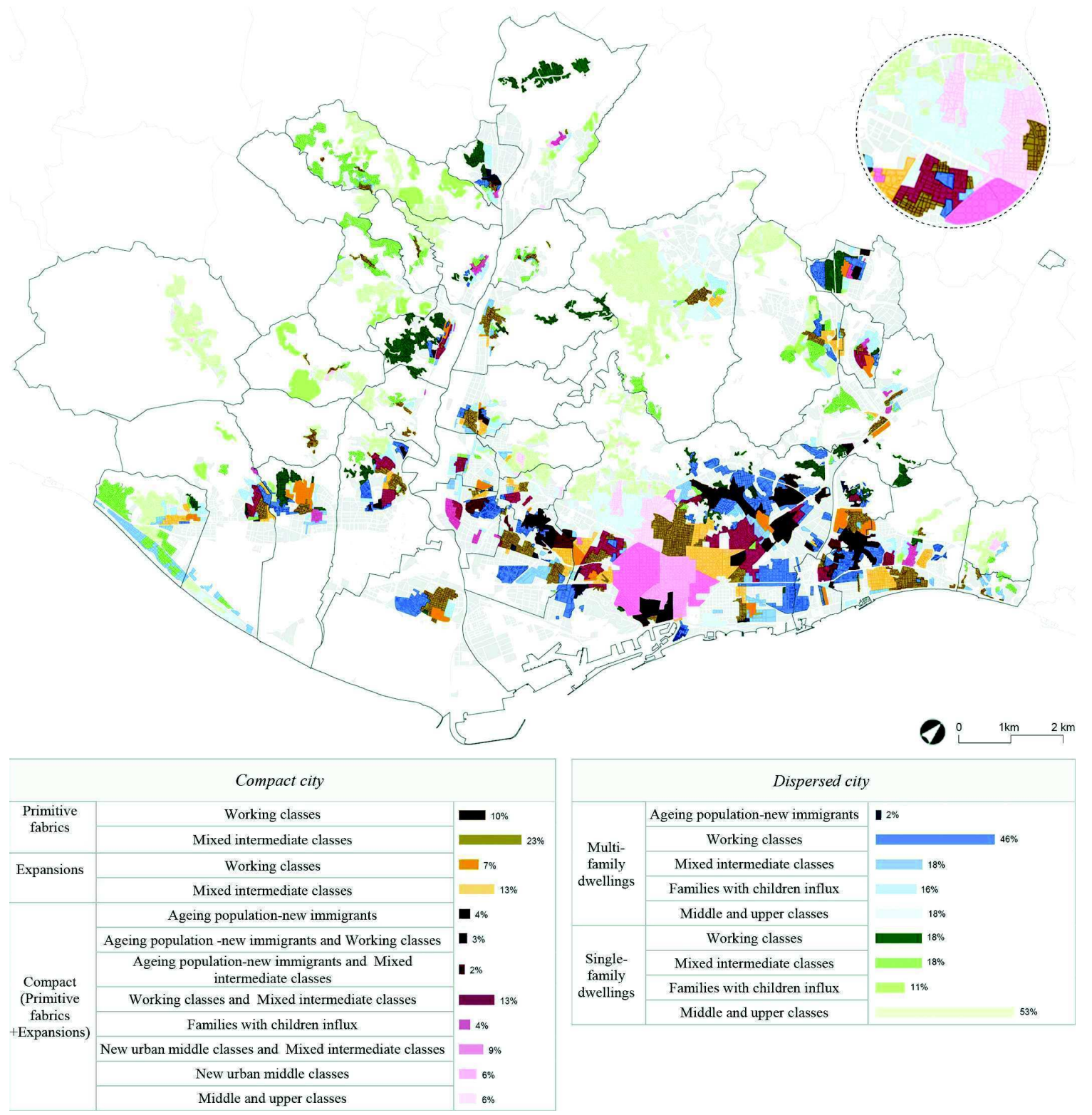

Figure 3.

Map of the socio-morphological structure of the Barcelona Metropolitan area with graphs of the proportion of land for each of the categories in relation to the categories of Compact, Multi-family dwellings and Single-family dwellings (SRPD-AMB, 2017)

shared status of compact city, they are named "Compacts". Next, sociologically speaking, in those cases where one of the two categories is "mixed intermediate classes", the other category is given priority, since the category "mixed intermediate classes" is the least conclusive of the six. Then, proportionally speaking, in those categories where one of the two is nearly $60 \%$ and the second is materially less, they are assimilated into the category closest to $60 \%$. Finally, in exceptional cases, agreed qualitative factors have been established for assimilation, taking into account knowledge of the territory and its social factors

The second phase, addresses re-assignment of the morphological and sociological information to those new zones. The statistical estimation method used to characterize the 21 types of socio-morphological fabrics falls within the scope of areal interpolation methods. Basically, this method allows proportional (re)assignment of the socio-economic and/or 
demographic information available for source zones to other target zones. In this case, the information was transferred from census tracts to socio-morphological fabrics. Specifically, the method used in this study was derived from the Cadastral-based Expert Dasymetric System (CEDS) (Maantay, Maroko and Herrmann; 2007: 77-102, and Mora-García and MartiCiriquian; 2015: 305-314). The underlying logic of the CEDS is that the population of the census tracts is broken down according to residential gross floor area in the Cadastre, to then regroup the population in the target zone. The formula used to make the (re)assignment of the information is the following:

$$
\mathrm{NHab}_{\text {parc }}=\frac{\mathrm{SCRes}_{\text {parc }} \cdot \mathrm{NHab}_{\mathrm{sc}}}{\sum \mathrm{SCRES}_{\mathrm{sc}}}
$$

Where NHabparc_viv is the number of inhabitants per cadastral parcel in accordance with the number of dwellings; SCResparc is the residential gross floor area in the cadastral parcel; NHabsc is the number of inhabitants in the census tract; and $\sum$ SCRessc is the total gross floor area in the census tract.

The outcome of that combination is the socio-morphological map of the Barcelona metropolitan area showing the resulting twenty-one categories ${ }^{1}$ used to describe for the first time jointly the physical and sociological aspects of the conurbation (Figure 3).

\section{Measurement and analysis}

The outcome of the combination methodology allow us to advance our socio-morphological knowledge based upon two factors: detailed description of each of the twenty-one sociomorphological categories and the reading of the resulting socio-morphological map.

The explanation of the 21 categories takes into account the morphological and sociological variables explained (Table 1 and Table 2), with special emphasis on the factors that intentionally accentuate the differences between them in order to ascertain the link between urban form and social cohesion. In that connection, the following two exemplary factors are noteworthy:

1.Certain morphological traits differentiate categories that belong to the same morphological category and are sociologically distinct. For example:

-Single-family dwellings for Middle and Upper Classes and Single-family dwellings for Working Classes: although both are Single-family Dwellings, they have different morphological indicators. For example, in the second case, the parcels are smaller by almost one half and the population and dwelling density are almost double.

-Multi-family dwellings for Ageing population-New Immigrants and Multifamily dwellings for Mixed Intermediate Classes: although both belong to Multi-family dwellings, the social status involve factors such as the fact that there is much higher building density in the former with less identity (fewer heritage listed) and more irregular topography.

2.There are characteristic sociological traits among categories that belong to the same sociological category and are morphologically distinct. For example, in Compact with Families with children influx and Singlefamily Dwellings with Families with children influx, although they belong to the same sociological category, unsafety in the Singlefamily Dwellings category is considerably higher, while connectedness is notably poorer. In addition, the non-Community population is below average in the Single-family Dwellings category while it is twice as high in the Compact category.

Both cases point up the very close relationship between sociological and morphological factors.

On a different subject, the reading of the map and its categories allows us to note, at first sight, the fact that Compact city has a higher sociological diversity than Dispersed city. For example, Single-family Dwellings lacks both Ageing Population and New urban classes, and Multi-family dwellings lacks New urban classes. Those facts, along with the need for a larger number of sociological categories and more heterogeneous categories to explain Compact city in comparison with Dispersed city, support that hypothesis.

On the other hand, in territorial terms, we can clearly identify the larger pieces making up the present-day urban structure of the 
Barcelona conurbation. The core portion of the downtown area is increasingly dominated by the new middle classes, with certain pockets of lower-income population. The other two zones of Middle and upper classes found in the city centre are connected to that core area. Adjacent to the downtown area there are transitional areas with a high degree of mixture of social make-up, which, within the residential system, are located between the Middle class residential areas and Working class residential areas. Beyond those transitional areas we clearly find two Working class hubs along the Besòs and Llobregat rivers. Finally, we find three low-density areas predominantly inhabited by Middle and upper classes. The largest one is located beyond the Llobregat hub. The second, more centrally located, comprises different areas of Esplugues de Llobregat and Sant Just Desvern, Vallvidrera (Barcelona) and certain developments in Sant Cugat and Cerdanyola del Vallès. The third such area is the smallest and located to the northeast, stretching in part from Badalona to Tiana and Montgat.

The following paragraphs set out a description of the social standing and territorial distribution of each of the major morphological groups and the resulting twenty-one categories: Compact, Multi-familw dwellings and Singlefamily dwellings.

In the case of the Compact City, a substantial portion of the land (80\%) is occupied by some category with Intermediate and working classes (Figure 3). Within that high proportion, the Primitive and Expansion with mixed intermediate classes occupy the greatest surface area $(36 \%)$. In second place we find, notably, that the Expansions, characterised as Working classes and Mixed intermediate classes, make up the third most important category in the compact city $(20 \%)$, followed by Historical with working classes $(10 \%)$. In respect of location within the territory, observation of the map allows us to note especially the following factors:

-The areas of Compact with Ageing population-New immigrants are found mainly in the municipalities with the highest populations and those most centrally located.

-The areas of New middle classes are located centrally and within Barcelona. Consequently, the central compact forms are the most likely to undergo processes of gentrification.

-The areas of Middle and upper classes are concentrated above Diagonal, in the upper part of Barcelona, Esplugues and Sant Just Desvern, as well as in Tiana.

-The areas of Intermediate classes are scattered, with presence in all the municipalities. While those located farther north are mostly isolated, along the coast they tend to border on other categories, mainly with areas of Working classes.

The areas of Multi-family dwellings are associated mainly with Working classes (46\%) (Figure 3). However, there are also areas in similar proportions with Intermediate classes, Families with children and Middle and upper classes (16-18\%). Finally, we find Ageing population-New immigrants in a much smaller proportion (2\%). Insofar as concerns location within the territory, a critical analysis of the map leads us stress the following factors:

-Areas with Working classes, Ageing population-New immigrants and Families with children influx are found in practically all the municipalities and they show certain distinctive aspects of location, situated mainly on the edges of urban centres and often with a certain relation of conflict with infrastructure elements that sit uneasily within an urban environment.

-Areas with Families with children influx are found in practically all the municipalities except Barcelona. They are located mainly on the periphery of urban continuums, but, unlike the previous category, they lack the relation of conflict with infrastructure elements.

-Areas with Mixed and intermediate classes and Middle and upper classes are located both on the periphery and within the urban continuum, but in all cases with a certain distance from the most undesirable infrastructure elements and proximity to public transportation services. They are differentiated by the fact that the former are found in a large number of municipalities, while the latter, on the other hand, are only found in Barcelona, Sant Cugat and Castelldefels.

Within the areas with Single-family dwellings, there is also a predominant social category: Middle and upper classes (53\%) (Figure 3). In second and third place we find 
areas with Working and intermediate classes $(18 \%)$ and areas with Families with children influx $(11 \%)$. In respect of location within the territory, we see the following factors:

-Areas with Middle and upper classes, those with Families with children influx and Mixed intermediate classes share their location in respect of the rest and are found mostly isolated from the urban continuum. On the other hand, they diverge in certain aspects, such as the fact that the areas with Middle and upper classes are largely located near the main metropolitan infrastructure elements, although in a relationship of harmonious co-existence with them, as they are located underground or buffered, while the others tend to be located in topographically more elevated zones, with views and on the sunlit side.

-Unlike the foregoing, the areas with Working classes are mostly located contiguously with the urban continuum, mainly in two situations: either in areas involving a conflictive relationship with infrastructure elements, which act as barriers, or in topographically elevated zones in the shade and with a poor degree of connectedness.

\section{Conclusion}

The combined social and morphological scrutiny within the context of the Barcelona metropolis allows us to discern the close relationship between urban form and social cohesion. There can be no doubt that the two factors condition each other, and thanks to the new socio-morphological map and the definition of the twenty-one socio-morphological categories presented, we can now determine that link in greater detail. In addition, the new map points up socio-morphological similarities between zones distant from one another and suggests shared urban strategies to encourage greater urban fairness. All in all, it supposes progress in awareness of the metropolitan reality that may become capital, to continue expanding that awareness and to consider key factors for improving its future.

In that connection, we must stress the future lines of research that will be derived from this new material generated. On the one hand, one of the opportunities could be the possibility of performing a more detailed diagnosis of urban cohesion. Working with quantitative indicators of socio-spatial criteria assessing the need for action in each of the twenty-one categories could provide guidelines for determining the most appropriate tools for transformation and the areas for priority intervention. On the other hand, taking into account the availability of sociological data from 1991, 2001 and 2011 and having established the methodology for combing the data on physical and sociological factors, another future line of research could be to address the time aspect. Reconstruction of the evolution of the socio-morphological structure will allow us to broaden the possibilities for analysis and to visualise processes, facilitating the understanding of certain phenomena and may generate knowledge to help foresee or prevent certain problems.

\section{Notes}

1 Denomination of socio-residential categories is changed when combined with morfological categories. Equivalent to: Middle and upper classes residential areas turns into Middle and upper classes; New urban middle classes neigbourhoods into New urban middle classes; Areas of families with children influx into Families with children influx; Mixed areas with intermediate classes into Mixed intermediate classes; Working class neighbourhoods into working classes; Old or deprived areas into Ageing population-new immigrants.

\section{References}

Busquets et al. (2015) Metròpolis Barcelona (Àrea Metropolitana de Barcelona, Barcelona).

Harvey, D. (1977) Urbanismo y desigualdad social (Siglo XXI, Madrid).

Maantay, J. A., Maroko, A. R. i Hermann, C. (2007). "Mapping population Distribution in the Urban Environment: The Cadastralbased Expert Dasymetric System (CEDS)" in Cartography and Geographic Information Science, $(34,2), 77-102$. 
Marcuse, P. i van Kempen, R. (2000) 'Conclusion: A Changed Spatial Order' in Marcuse, in P. i Van Kempen, R. (eds.) Globalizing Cities: A New Spatial Order? (Blackwell, Oxford), 249-275.

Marcuse, P. (2002) 'The Partitioned City in History', in P. Marcuse i R. Van Kempen (Ed.) Of States and Cities: The Partitioning of Urban Space (Oxford: Oxford University Press), 11-34.

Mora-García, R. T. i Martí-Ciriquian, P. (2015). "Desagregación poblacional a partir de datos catastrales". In A J. de la Riba, P. Ibarra, R. Montorio i M. Rodrigues (eds.), Análisis espacial y representación geográfica: innovació y aplicación (Zaragoza: Universidad de Zaragoza-AGE), 305-314.

Porcel, S. (2016) 'Dinámicas de restructuración socioresidencial en la Barcelona metropolitana postindustrial: ¿hacia una ciudad dual o cuarteada?', unpublished $\mathrm{PhD}$ thesis, Departament de Sociologia, Universitat Autònoma de Barcelona, Barcelona.

Porcel, S.; Navarro-Varas, L.; Thiers, J. (2015) “L'evolució de l'estructura socioresidencial de l'àrea metropolitana de Barcelona: dinàmiques de diferenciació residencial $\mathrm{i}$ desigualtat urbana en la ciutat postindustrial" in IERMB Working Paper in Sociology (15.03).

Sarasa, S., Porcel, S., Navarro-Varas, L. (2013) L'impacte social de la crisi a l'àrea metropolitana de Barcelona i a Catalunya", in Papers: Regió Metropolitana de Barcelona (L'impacte de la crisi a l'Àrea Metropolitana de Barcelona i a Catalunya, 56), 10-88.

Secchi, B. (2015) La ciudad de los ricos y la ciudad de los pobres (Catarata, Madrid).

Solà-Morales, M (1993) Les formes de creixement urbà (Universitat Politècnica de Catalunya, Barcelona).

Vilanova, JM. (1997) "Les trames residencials en la Barcelona metropolitana" in Papers: Regió Metropolitana de Barcelona (Les formes del creixement metropolità, 26), 5370.

Vinyes, R., Figueras, M. and Molist, L. (2016) "Estudi dels teixits morfològics residencials" unpublished study Àrea Metropolitana de
Barcelona, Barcelona.

Vinyes, R., Figueras, M. and Molist, L. (2016) 'Estudi teixits morfològics residencials'. (Àrea Metropolitana de Barcelona, Barcelona). 